\title{
Transcranial Doppler Study Among Children with Sickle Cell Anaemia Vs Normal Children
}

\author{
Lakhkar BB' ${ }^{1}$ Lakhkar BN², Vaswani P3 \\ ${ }^{1}$ Dr. BB Lakhkar, MBBS, MD, Prof. and Head of Department, ${ }^{2}$ Dr. BN Lakhkar, MBBS, MD, DMRD, ${ }^{3}$ Dr. Paresh Vaswani, MBBS, \\ PG Resident in Paediatrics. All from the Acharya Vinoba Bhave Hospital, JNM College, Sawangi, Wardha, Maharastra, \\ India.
}

Address for correspondence: Dr. BB Lakhkar, E-mail: blakhkar@yahoo.co.in

\begin{abstract}
Introduction: Role of transcranial Doppler in prevention of stroke in sickle cell children has been well appreciated. Studies are being done to develop the protocol in children. Since we don't find stroke very commonly in this part of the world, this study was done in order to see the prevalence of abnormal flow velocity in sickle children attending sickle cell clinic. The aims of this study were to measure mean flow velocity in different vessels in homozygous sickle cell patients using transcranial Doppler study, to compare the mean velocity in sickle children with age and sex matched controls and to correlate mean velocity with headache or stroke if any and also to correlate mean velocity with number of transfusions. Materials and Methods: The study was done in Paediatric wards. It was a prospective crosssectional comparative study. Twenty six children below 14yrs of age with homozygous sickle cell disease attending the Sickle cell clinic were selected as the cases. Forty cases of similar age and sex were recruited as normal control group. Transcranial Doppler was done in six different vessels in both the groups and mean flow velocity was measured. Mean flow velocity was correlated with symptoms and number of transfusions. Velocity was classified as normal $(<170 \mathrm{~cm} / \mathrm{sec})$, conditional $(170-199 \mathrm{~cm} / \mathrm{sec})$ or abnormal $(>200 \mathrm{~cm} / \mathrm{sec})$. Statistical analysis was done using SPSS 10 software. Results: In normal age and sex matched controls mean blood flow velocity was $50 \mathrm{~cm} / \mathrm{sec}$ where as in the cases of sickle cell disease was $180 \mathrm{~cm} / \mathrm{sec}$. Maximum mean velocity was observed in middle and posterior cerebral artery. In two Sickle cell cases (8\%) blood flow velocity was abnormal, these children had headache though received 5-10 transfusions/year. In only 4\% sickle cell children flow velocity was normal and rest had conditional velocity. Among these children $39 \%$ received less than 5 and rest received 5-9 transfusions /yr and had no symptoms of stroke. Conclusions: Flow velocity measured by Transcranial Doppler is highest in middle cerebral artery and Posterior cerebral artery which appear to be the best arteries for this test in this region. Flow velocity was significantly high in children with sickle cell disease as compared to normal children. Prevalence of abnormal flow velocity in our children was $8 \%$ and children with abnormal mean flow velocity presented with headache.
\end{abstract}

Key words: Transcranial Doppler, Homozygous sickle cell, Stroke, Flow velocity.

\section{Introduction}

W ardha district is situated in Vidarbha region of central India and this area is popularly called sickle belt due to high prevalence of this condition. Acharya Vinoba Bhave Rural Hospital is running a sickle cell clinic where registration, free treatment and follow up of these patients is done regularly.

Manuscript received: $09^{\text {th }}$ Jan 2012

Reviewed: $15^{\text {th }}$ March 2012

Author Corrected: $15^{\text {th }}$ April 2012

Accepted for Publication: $30^{\text {th }}$ April 2012
Prevalence of Stroke in children with sickle cell disease is described to be around 7 to $12 \%{ }^{1,2,3}$. Stroke Prevention Trial (STOP) I and II trials were done for its prevention and showed that regular transfusion, based on report of transcranial Doppler, can effectively prevent stroke ${ }^{4,5}$.

Our patients rarely complained of headache and limb weakness. This study was done out of curiosity to see whether our patients differed from patients elsewhere? May be they are already receiving too many transfusions for other reasons which keeps the velocity 
low and hence prevents stroke. This study is an effort to compare flow velocity in different vessels of children with sickle cell disease and normal children.

The objectives of this study were 1) To measure mean flow velocity in different vessels in homozygous sickle cell patients using transcranial Doppler study. 2) To compare the mean velocity in sickle children with age and sex matched controls. 3) To correlate mean velocity with headache or stroke if any. 4) To correlate mean velocity with number of transfusions.

\section{Materials and Methods}

It was a prospective observational study. Children below 15yrs diagnosed as sickle cell anemia (by hemoglobin electrophoresis) and attending sickle cell clinic for 1 year were included in the present study. Age and sex matched normal children attending Paediatric OPD for minor illnesses were used as controls. Detail history including presenting symptoms, number of transfusions and examination features were noted. Transcranial Doppler study was done over internal, external and common carotids, middle and posterior cerebral and vertebral artery on right side using 500 MDMR3 ultrasound color Doppler machine with 2-3 $\mathrm{MHZ}$ probe. The velocity over the vessel was noted.

Doppler study was done after acute stage (crisis) was over. The velocities were noted and correlated with symptoms and number of transfusions. Other investigations were done as indicated. below.

As per STOP study ${ }^{1,2}$ velocities were classified as

Normal $-<170 \mathrm{~cm} / \mathrm{sec}$

Conditional - 170-199c m/sec

High or abnormal- $>200 \mathrm{~cm} / \mathrm{sec}$

\section{Results}

Doppler study was done in 26 sickle cell homozygous patients and 40 normal controls. Their age and sex wise distribution is given in Table 1.

Fever (60\%), bone pain (60\%) and pain in abdomen (39\%) were most common complaints. Around 14\% patients complained of pale skin and only $8 \%$ presented with headache. On examination most common finding was pallor (20\%) and fever (18\%). Systemically bones and joint problems and hepato-splenomegaly were most common finding (53\% each). Only 2 (8\%) children presented with headache, none had hemiparesis.

Around 39\% children with sickle cell anaemia received less than 5 and rest received 5-10 transfusions per year. Children with headache (8\%) received 5-10 transfusion/yr.

Among sicklers only 2 children (8\%) had flow velocity which was abnormal ( $>$ than $200 \mathrm{~m} / \mathrm{sec}$ ) and they were the same children who presented with headache. Majority (88\%) of sickle children had conditional values. Among normal children all had mean velocity below 170 $\mathrm{cm} / \mathrm{sec}$ (Table 2).

Highest mean velocity was found in middle cerebral artery $(155 \mathrm{~cm} / \mathrm{sec})$ followed by post cerebral artery $(149 \mathrm{~cm} / \mathrm{sec})$ and common carotid artery $(131.8 \mathrm{~cm} / \mathrm{sec})$. Minimal velocity was $88 \mathrm{~cm} / \mathrm{sec}$ in vertebral artery. This artery also showed widest variation which might reduce its reliability.

Table 1: Age and sex wise distribution of subjects

\begin{tabular}{|c|c|c|c|c|c|c|}
\hline \multirow[t]{2}{*}{ Age } & \multicolumn{3}{|c|}{ Sickle Patients } & \multicolumn{3}{|c|}{ Normal Patients } \\
\hline & Male & Female & Total & Male & Female & Total \\
\hline$<5 y r s$ & 10 & 2 & 12 & 2 & 10 & 12 \\
\hline 5-10 yrs & 7 & - & 7 & 5 & 8 & 13 \\
\hline$>10$ yrs & 2 & 5 & 7 & 12 & 3 & 15 \\
\hline Total & 19 & 7 & 26 & 19 & 21 & 40 \\
\hline
\end{tabular}

Table 2: Subjects at a glance

\begin{tabular}{|l|c|c|c|c|}
\hline & \multicolumn{2}{|c|}{ Sickle Patients } & \multicolumn{2}{c|}{ Normal Patients } \\
\hline Mean velocity(cm/sec) & Number & Percentage & Number & Percentage \\
\hline Normal $(<170)$ & 1 & $4 \%$ & 40 & $100 \%$ \\
\hline Conditional(170-199) & 23 & $88 \%$ & & \\
\hline High risk $(>200)$ & 2 & $8 \%$ & & \\
\hline
\end{tabular}


Table 3: Velocity in different vessels at a glance

\begin{tabular}{|l|c|c|c|}
\hline & \multicolumn{2}{|c|}{ Sickle Patients (N=26) } \\
\hline Arteries & Above 170 & Mean & Range \\
\hline Middle cerebral artery & 15 & 155.5 & $140-220$ \\
\hline Posterior cerebral artery & 12 & 149 & $130-190$ \\
\hline Common carotid artery & 4 & 131.8 & $100-175$ \\
\hline Internal carotid artery & - & 131 & $90-150$ \\
\hline External carotid artery & - & 115.6 & $100-145$ \\
\hline Vertebral artery & - & 88 & $80-160$ \\
\hline
\end{tabular}

\section{Discussion}

The prevalence of stroke described in sickle cell children ${ }^{1}$ is around $10-12 \%$. In the present study only $8 \%$ children presented with headache without any neurodeficit.Some authors have found silent infarcts on neuroimaging ${ }^{6}$. We might have missed silent infarcts as we could not do neuroimaging due to financial constraint.

The vessels used for doppler in STOP trial ${ }^{5}$ were distal internal carotid and proximal middle cerebral arteries, We used all the vessels namely external carotid, internal carotid, common carotid, middle and posterior cerebral artery and vertebral artery. We wanted to see which artery gives highest velocity in our set up which in turn informs the site of stroke. Highest mean velocity found was in middle and posterior cerebral artery followed by common and internal carotids. Gordman and collegue used submandibular Transcranial Doppler and could pick up cases missed using internal carotid?

In normal children mean velocity was in normal range $(<170 \mathrm{~cm} / \mathrm{sec})$ where as in sickle children only 1 had normal velocity. Among sicklers $8 \%$ had abnormal and rest had conditional values. This shows our children are at risk of stroke but may be the velocities are just below abnormal values as 39\% receive transfusion at least once in 2 months. Regular transfusions prevent first stroke as shown in STOP trial ${ }^{3}$. This fact does not explain Two children in our study with headache and higher velocities (>200m/sec) who were receiving 5-10 transfusions per year.

MR Angiography (MRA) has been correlated with Transcranial Doppler ${ }^{5}$ and MRA was found abnormal if TCD was abnormal. On transfusion, abnormalities normalize only if velocity normalizes. This emphasizes that noninvasive and cheaper transcranial Doppler is a good screening method to detect stroke. This finding might also suggest need to start transfusion therapy before vasculopathy sets in.

Result of STOP trial II clearly showed increase in stroke after stopping chronic transfusion therapy ${ }^{8}$
Heather et al. ${ }^{9}$ showed decreasing trend in stroke since children were on chronic transfusion therapy. Pegelow Macklin and Moser studied MRI in 266 sickle children and found infarcts(including silent ones) in $21 \%$ children and reported recurrence more common in children with silent infarcts ${ }^{10}$. Majumdar et al compared 6 different strategies of chronic transfusion and found screening with doppler upto the age of 6 and transfusion therapy up to age of 18 was the best strategy. Regular chelation therapy improved outcome ${ }^{11}$. Scothorn and Price studied 137 children who were on chronic transfusion therapy for $5 \mathrm{yrs}$ and found recurrent stroke is more common if first stroke was not with any other medical event like other types of crises $^{12}$.

Left and right velocity differences may be useful in identifying unilateral narrowing. Reference values in sickle cell children have been given by Krejza J et.al. ${ }^{13}$. In this study we could do TCD only on right side hence comparison was not possible.

Some authors also found other uses of abnormal TCD values ${ }^{6,14}$. Kral et al found children with abnormal TCD values performed more poorly than children with conditional TCD values on measures of verbal intelligence and executive function ${ }^{14,15}$. Infarctions may remain silent as far as neurodeficit is concerned but may give rise to poor intelligence as sequel ${ }^{15,16}$. This aspect also needs further evaluation as it may be worthwhile to give chronic transfusion for better performance of children. Yerys and White showed better performance of children with memory strategy education as compared to only tutorials ${ }^{17}$. This study also emphasizes importance of screening for infarcts.

Overall this study shows that our children also are at risk of stroke as in other studies and TCD can be a screening method and should be used in sickle cell clinic regularly.

\section{Conclusions}

Flow velocity measured by Transcranial Doppler is highest in middle cerebral artery and Posterior cerebral artery which appear to be the best arteries for this test in 
this region. It is significantly high in children with sickle cell disease as compared to normal children. Prevalence of abnormal flow velocity in our children is $8 \%$. Children with abnormal mean flow velocity presented with headache.

\section{Acknowledgements: Nil}

Funding: This study was sponsored by Datta Meghe Institute of Medical Sciences University Nagpur, India.

Conflict of interest: Nil

Permission from IRB: Yes

\section{References}

1. Ohene-Frempong $\mathrm{K}$, Weiner $\mathrm{S}$, Sleeper $\mathrm{L}$ etal. Cerebrovascular accidents in sickle cell disease; rates and risk factors. Blood 1998;91:288-94.

2. Lanzkowsky P: Hemolytic Anemias. Manual of pediatric hematology oncology, $4^{\text {th }}$ edn Elsevier academic press 2005. 136-198.

3. Adams RJ, Mckie VC, Carl EM etal. Long term stroke risk in children with sickle cell disease screened with transcranial Doppler. Ann Neurol 1997;42:699-704.

4. Adams R, Mckie V, Hsu L et. al. Prevention of a first stroke by transfusion in children with abnormal results of transcranial Doppler Ultrasonography. $\mathrm{N}$ Eng J Med 1998;339:5-11.

5. Minniti CP, Gidvani VK, Bulas D, Brown WA, Vezina $G$, Driscoll MC. Transcranial Doppler changes in children with sickle cell disease on transfusion therapy. J Pediatr Hematol Oncol 2004;26(10):626-30.

6. Bernaudin F, Verlhac S, Fréard F, Roudot-Thoraval F, Benkerrou $M$, Thuret I, et.al.Multicenter prospective study of children with sickle cell disease: radiographic and psychometric correlation. Child Neurol 2000;15(5):333-43.

7. Gorman MJ, Nyström K, Carbonella J, Pearson H. Submandibular TCD approach detects post-bulb ICA stenosis in children with sickle cell anemia. Neurology 2009;73(5):362-5.

8. NHLBI Stops Study Testing How Long Children with Sickle Cell Anemia Should Have Blood Transfusions to Prevent Stroke: Clinical Alert Issued to U.S. Physicians. Available at: http://www.nhlbi.nih.gov/ new/press/04-12-05.htm (Accessed; 4th March 2012).

9. Heather JF, Robert JA, Shoujun ZS. Claiborne J. Declining stroke rates in Californian children with sickle cell disease. Blood 2004;104:336-39.

10. Pegelow $\mathrm{CH}$, Macklin EA, Moser FG et al Longitudinal changes in brain magnetic resonance imaging findings in children with sickle cell disease. Blood 2002;99(8):3014-8.

11. Mazumdar M, Matthew M. Heeney, Tracy A. Preventing Stroke Among Children With Sickle Cell Anemia: An Analysis of Strategies That Involve Transcranial Doppler Testing and Chronic Transfusion. Pediatrics 2007;120(4):1107-16.

12. Scothorn DJ; Price C; Schwartz D. Risk of recurrent stroke in children with sickle cell disease receiving blood transfusion therapy for at least five years after initial stroke. J Pediatr 2002;140(3) 348-54.

13. Krejza, J, Chen R, Romanowicz G, Kwiatkowski J L, Chord R, Arkuszewski M et. al. Sickle Cell Disease and Transcranial Doppler Imaging.InterHemispheric Differences in Blood Flow Doppler Parameters. Available as http/stroke.ahajournals. org/content/42/1/81. (Accessed $26^{\text {th }}$ March 2012).

14. Mary C. Kral, Ronald T. Brown, Paul J. Nietert. Transcranial Doppler Ultrasonography and Neurocognitive Functioning in Children with Sickle Cell Disease. Pediatrics 2003;112(2):324-31.

15. Mary C, Kral, Ronald T, Brown. Transcranial Doppler Ultrasonography and Executive Dysfunction in Children with Sickle Cell Disease. J Pediatr Psychol 2004;29(3):185-95.

16. Armstrong FD, Thompson RJ, Wang W, Zimmerman $\mathrm{R}$, Pegelow $\mathrm{CH}$, Miller S, et. al. Cognitive functioning and brain magnetic resonance imaging in children with sickle cell disease. Pediatrics 1996;97:864-70.

17. Yerys BE, White DA, Salorio CF et.al. Memory strategy training in children with cerebral infarcts related to sickle cell disease. J Pediatr Hematol Oncol 2003; 25(6):495-8.

\section{How to cite this article?}

Lakhhar BB, Lakhhar BN, Vasvani P. Transcranial Doppler Study Among Children with Sickle Cell Anaemia Vs Normal Children. J Nepal Paediatr Soc 2012;32(2):146-149. 